\section{CONTRIBUTION TO FRESHWATER DECAPODA (CRUSTACEA: ARTHROPODA) FROM UJANI WETLAND, MAHARASHTRA}

\author{
S.G.Patil \\ Zoological Survey of India, Western Regional Station, Vidhyanagar, \\ Sector 29, PCNT Post, Rawat Road, Pune, Maharashtra 411044, India.
}

Crustacean fauna constitutes prawn, crab, shrimps, wood lice, fish lice, barnacles and lobsters. Majority of them are aquatic, and breathe through gills or general surface of the body. Decapoda is a highly evolved and the largest order of Crustacea with about 8500 species. Culture of prawn and crabs in India have gained much importance in the recent years both for domestic consumption and also for export. Families Palaemonidae and Potamonidae constitute major fisheries of India. Majority of them are marine forms with cylindrical body. Segmentation of the body is conspicuous except in smaller forms. They are characterised by two pairs of antennae of which one pair is called antennules. Important contributions on freshwater decapods were by Chopra (1930), Chopra and Tiwari (1947), Ramakrishna (1950), Tiwari (1955), Vasisht and Singh (1972), Ghosh et al. (1993), Ghosh (2000), and, Ghosh and Ghatak (2000).

Ujani Wetland is about $120 \mathrm{~km}$ from Pune $\left(18^{\circ} 03^{\prime} \mathrm{N} \& 74^{\circ} 38^{\prime} \mathrm{E}\right)$ situated at the border of three districts i.e. Solapur, Pune and Ahmednagar, covering an area of 35,000ha. The shallow water is predominated by many aquatic weeds. The wetland is well known for its waterfowl and large flocks of Greater Flamingo which enjoy a greater part of the year in this wetland. The depth of water was 1-20m, $\mathrm{pH}$ of the water was between 5.8-8.2. Carbon di-oxide when detected was always above $12 \mathrm{mg} / \mathrm{L}$. Dissolved oxygen ranged from 3.8-8.6 mg/L. Hardness was above $50 \mathrm{mg} / \mathrm{L}$. All crustacean samples were collected with the help of water net and preserved in $70 \%$ rectified spirit.

Hydrobiological and faunistic studies of this wetland was conducted by the Western Regional Station of Zoological Survey of India, Pune, for preparation of a wetland inventory (Patil \& Singh, in press; Patil, in press).

Crustacean collections of Ujani Wetland revealed the existence of three species of family Palaemonidae and one species of family Potamonidae which are first records for the wetland. Following species of crustacea were identified from Ujani Wetland by the crustacea division of Zoological Survey of India, Kolkata.

Class: Crustacea; Order: Decapoda; Family: Palaemonidae Macrobrachium lamarrei lamarrei (Edwards)
Rostrum equal or longer than antennal scale, upper edge of rostrum with a gap between proximal series of 5-9 teeth and distal 1-2 subapical teeth, lower margin with 4-9 teeth, second prepods smooth slender equal or shorter than body length, carapace subequal to rostrum.

Distribution: Kolkata Salt Lake, Port Canning Uttarbag, Chennai.

Macrobrachium kistnensis (Tiwari)

The specimen with well developed rostrum. It is toothed and has compressed carapace armed with antennal and hepatic spine, distal of the rostrum generally curved, upper margin with teeth. Rostrum proportionately longer, cornea broader than eye stalks.

Distribution: Ujani Wetland, Maharashtra.

Remarks: Common in Ujani Wetland.

Macrobrachium rosenbergi (de Man)

Rostrum long and distally curved upwards, extended up to lip of antennal scale or little longer. Upper edge of rostrum with 10-16 and lower with 8-14 teeth, last three prepod slender of which $5^{\text {th }}$ much more slender than third. Tip of telson somewhat rounded and extend beyond lip of longer posterior spine, second prepod same length as palin.

Distribution: Punjab, Surat, Mumbai, Malabar District, Cochin, Chennai, Godavari District, Sunderban.

Family: Potamonidae

Paratelphusa (Barytelphusa) jacquemontii Ruthbun

In the abdomen of the adult male the length of $6^{\text {th }}$ segment is equal to its greatest breadth, the segment being squarish with the side slightly concave, the length of $7^{\text {th }}$ segment exceeds its greatest breadth.

Distribution: Dwarka, Kathihar, Rajputana, Uttar Pradesh, Orissa.

\section{Acknowledgements}

The author is thankful to Dr. J.R.B. Alfred, Director, ZSI, Kolkata; to Dr. Anil S. Mahabal, Scientist 'E' and Officer-in-Charge, ZSI, Pune; and to Officer-in-charge, crustacea section, ZSI, Kolkata for identification of the collection.

\section{References}

Chopra, B. (1930). Further notes on Crustacea, Decapoda in Indian Museum. Records of the Indian Museum 32(4): 413-430

Chopra, B. and K.K. Tiwari (1947). Decapod crustacea of Patna State, Orissa. Records of the Indian Museum 45: 213-224.

Ghosh, S.K. (2000). Palaemonidae (Crustacea: Decapoda). State fauna series 7: Fauna of Tripura, part 4, Pp. 267 - 272.

Ghosh, H.C. and S.S. Ghatak (2000). Decapoda: Potamonidae State fauna series 7: Fauna of Tripura part 4, Pp. 273-275.

Ghosh, S.K., Roy, T. and S. Bhadra (1993). Fauna of Meghalaya Palaemonidae (Crustacea: Decapoda), ZSI Publication.

Patil, S.G. (in press). Limnological investigations of Ujani Wetland.

Patil, S.G. and D.F. Singh (in press). Limnological investigations of Ujani Wetland abiotic factors, ZSI Publications.

Ramakrishna (1950). Notes on some Indian Potamonid Crabs (Crustacea: Decapoda). Records of the Indian Museum 48: 89-92.

Tiwari, K.K. (1955). New species and sub-species of freshwater Prawns. Records of the Indian Museum 52(1 \& 2): 297-300.

Vasisht, H.S. and Singh (1972). Crustacean fauna of Sukhana Lake. Records of the Bulletin (N.S.), Punjab University 23 (1 \& 2): 115. 